\title{
The level of ambient sounds as an indicator of urban road safety
}

\section{Filip Živkovića}

${ }^{a}$ Faculty of Transport and Traffic Engineering, University of Belgrade, Vojvode Stepe 305, Belgrade, Republic of Serbia

\begin{tabular}{|c|c|}
\hline ARTICLE INFO & A B S T R A C T \\
\hline $\begin{array}{l}\text { DOI: } 10.31075 / \mathrm{PIS} .66 .04 .02 \\
\text { Professional paper } \\
\text { Received: 06/09/2020 } \\
\text { Accepted: 01/12/2020 } \\
\text { Corresponding author: } \\
\text { fica.zivkovic@gmail.com } \\
\text { Keywords: } \\
\text { Traffic related noise } \\
\text { Urban road safety } \\
\text { Public health } \\
\text { Road safety indicator }\end{array}$ & $\begin{array}{l}\text { Traffic in urban areas has led to environmental noise pollution. However, traffic } \\
\text { is not only source of noise, so environmental noise is referred to as a communal } \\
\text { noise, which is combination of several sources. All sources may lead to } \\
\text { consequences on human health such as: stress, tinnitus, cardiovascular and } \\
\text { respiratory diseases and death in extreme cases. In this regard, ambient sound } \\
\text { levels were measured at } 19 \text { locations in the city of Belgrade, during the winter } \\
\text { and summer period. The aim of this paper is to show ambient sounds level as } \\
\text { an indicator of urban road safety, based on which it would be possible to } \\
\text { complete the goals of creating cities suitable for the life of citizens. } \\
\text { Measurement of ambient sound level in the city of Belgrade showed that the } \\
\text { noise level exceeds the allowed limits (in range from 0.5dB to } 20.3 \mathrm{~dB} \text { ) at most } \\
\text { location, which distinguishes noise as a significant pollutant of the environment } \\
\text { in Belgrade, and to which traffic significantly contributes. }\end{array}$ \\
\hline
\end{tabular}

\section{Introduction}

The advantages of traffic were known even with the appearance of the first automobiles, however, as traffic developed more and more, so did the consequences that traffic has on the social, health and economic aspects of human life. Some of the consequences of traffic are traffic accidents (property damage, number of injured and dead people), resources depletion, environmental pollution by exhaust gases, noise, stress caused by participation in traffic, social pollution, physical inactivity and the like.

Traffic accidents, i.e. their consequences, are the biggest negative effect of traffic, with 1.35 million fatalities per year (where traffic accidents are the eight cause of death of all age groups and the first cause of death of children and youth (5-29 years)) (WHO, 2018). However, traffic also contributes to air pollution through exhaust gases and pollutants, leading to climate change, which has killed more than 150,000 lives with the development of cardiovascular disease and cancer calls since the beginning of this century (Douglas et al., 2011), especially among vulnerable road users (pedestrian and cyclist).
In addition, noise as consequences of traffic is a harmful consequence that particularly affects urban areas. Traffic related noise can have short- and longterm consequences that can have different effects on humans. It is estimated that noise affects the loss of 1.0-1.6 million healthy years of life in the European Union on an annual basis (WHO, 2011). Since the majority of the Europe population is exposed to daytime noise higher than $65 \mathrm{~dB}$ (night level $-55 \mathrm{~dB}$ ) (Recio et al., 2016), this is not a surprising fact. Although the impact of noise is strongest in urban areas, but it also depends on the characteristics, intensity and nature of the sound (Münzel et al., 2017).

In urban areas, noise can occur from traffic, during construction and industrial works, from community (radio, television, restaurants, etc.) and from social and leisure sources (concerts, telephone use, recreation, etc.) (WHO, 2011; Pecic and Pravdic, 2019). However, traffic (especially road traffic) significantly contributes to noise as a source of environmental pollution (Münzel et al., 2017; EEA, 2017; Yang et al., 2020). For example, an automobile moving at $35 \mathrm{~km} / \mathrm{h}$ $(21.7 \mathrm{mph})$ creates a noise level of $50 \mathrm{~dB}$, and an automobile moving at $75 \mathrm{~km} / \mathrm{h}(46.6 \mathrm{mph})$ creates a noise level of 59dB (Mihajlovic i Stosic, 2016; Pecic and Pravdic, 2019). 
As already mentioned, noise as a consequence of traffic can have short- and long-term consequences for humans. Of course, a much large number of people are affected by noise than the number of those who have consequences from it (WHO, 2011). The noise consequences, which are among the consequences of lower intensity are various forms of stress, sleep disorders, tinnitus, cognitive impairment, reduced learning ability in children and adolescents, obesity and high blood pressure in all age groups (Andersson et al., 2020; Yang et al., 2020; Pecic and Pravdic, 2019; Münzel et al., 2017; Mihajlov et al., 2015). However, although these consequences belong to the group of short-term consequences, they can lead to increased use of medication for hypertension (Münzel et al., 2017), but also with increased medical prescribing of anxiolytics (Klompmaker et al., 2019).

When it comes to the long-term consequences that noise can have on a human, the fallowing stand out: hearing loss, cardiovascular diseases (especially myocardial infarction and permanent hypertension), the risk of diabetes (type 2), respiratory diseases, metabolic syndrome (combination of diseases caused by diabetes, obesity and hypertension) and development of mental disorders and Alzheimer's disease (Andersson et al., 2020; Oudin, 2020; So et al., 2020; Yang et al., 2020; Yu et al., 2020; Héritier et al., 2019; Pecic and Pravdic, 2019; Münzel et al., 2017; Recio et al., 2016; Mihajlov et al., 2015; Sygna et al., 2014). However, in addition to the development of the disease, noise can also contribute to the premature appearance of genetically inherited diseases (Pecic and Pravdic, 2019), and in extreme cases it can also lead to death (WHO, 2011). In addition, there are authors who believe that long-term exposure to noise can contribute only to a small risk of various diseases (Halonen et al., 2015), but also those who believe that noise cannot contribute to the development of long-term consequences (Klompmaker et al., 2020).

However, since the noise is not the only consequences of traffic in urban areas, a number of authors argue that it is necessary to observe noise in conjunction with air pollution, because it has shown that these are two of traffic pollutant that contributes to the development of numerous diseases in humans (So et al., 2020; Tezel et al., 2019; Recio et al., 2017).

The report on the implementation of the G2G project for Serbia (G2G09/SB/5/5, 2011) showed that more than $60 \%$ of the urban population in Republic of Serbia is exposed to the level of traffic noise pollution which can seriously impair the quality of life. In one study which measured the level of noise pollution in Belgrade (Antic et al. 2012.) the data from 30 measuring points in the period from 2006 to 2010 were used.
Data for day (06.00-22.00) and night (22.00-06.00) noise period were collected from the mentioned points, and all locations were divided into seven zones: residential zone, zone with high volume of traffic, central city zone, industrial zone, hospital zone, school zone and recreation zone. The result show that the Ugrinovačka Street in Zemun, as a representative of the residential zone, is the most polluted by noise, with a daily level of $75 \mathrm{~dB}$ and a night level of $70 \mathrm{~dB}$ (2006). The Despot Stefan Boulevard (a zone with high volume of traffic) was the most polluted by noise both during the day and night period $(82 \mathrm{~dB}$ and $76 \mathrm{~dB}$, respectively) during 2010, while Zeleni Venac (central city zone) was the most polluted part of the city (with $73 \mathrm{~dB}$ and $70 \mathrm{~dB}$, respectively) during 2007 and 2008 . On the other hand, field measurements carried out in Kragujevac in 2018 at six locations (city center, main roads, residential zone, hospital zone, rest and recreation zone, zone on the border with the industrial zone) during fifteen-minute intervals showed that the mean value of the noise level does not exceed the permissible limits of the noise level (Djuric et al, 2018).

Since urban road safety (URS), a branch of road safety as a scientific discipline, which will show its importance in creating sustainable cities during coming period (Zivkovic and Todorovic, 2020), the aim of this paper is to define ambient sound levels as an indicator of URS on the example of the city of Belgrade. In this way, it will be possible to supplement the goal of creating cities suitable for human life, where the aim is not only to reduce traffic accident and their consequences but also to reduce all the negative effects of traffic.

\section{Sound as a source of noise}

Sound is a physical quantity consisting of waves moving through the air (PIARC, 2020). However, although it is based on clear physical laws, noise is experienced subjectively, and represents any unwanted sound. In other words explained, what one person perceives as a pleasant sound, another person may experience as an undesirable sound that causes disturbance or stress.

According to EC Directive (2002/49/EC) environmental noise is defined as "unwanted or harmful outdoor sound created by human activities, including noise emitted by means of transport, road traffic, railway traffic, air traffic, as well as noise from industrial areas."According to the guidelines of the World Health Organization (WHO, 2011), many sources of noise in the environment (especially in urban areas) to which people are exposed have been defined. Some of these sources are: Traffic (road traffic, railway traffic, air traffic); Construction and industry; Community sources (neighborhood, radio, TV, bars and restaurants, etc.); Social and leisure sources (listening to music, fireworks, toys, concerts, etc.). 
Traffic is the biggest source of noise pollution in urban areas. However, when measuring the level of ambient sounds in the field, it is impossible to single out the noise level as a consequence of traffic, from other socalled communal sounds (sum of all noise sources in the environment). In this regard, the continuation of work will be based on communal sounds, i.e. communal noise as an indicator of urban traffic safety, which strives to create cities that are suitable for human life (Zivkovic and Todorovic, 2020).

\section{Methodology}

The level of ambient sounds (noise) was measured using the Decibel X:dB Sound Level Meter (SkyPaw Co. Ltd) mobile application (Figure 1.). The noise level was measured at 19 locations in Belgrade, which were divided into four zones: residential zone, zone with high volume of traffic, recreation zone and central city zone (Table 1.).

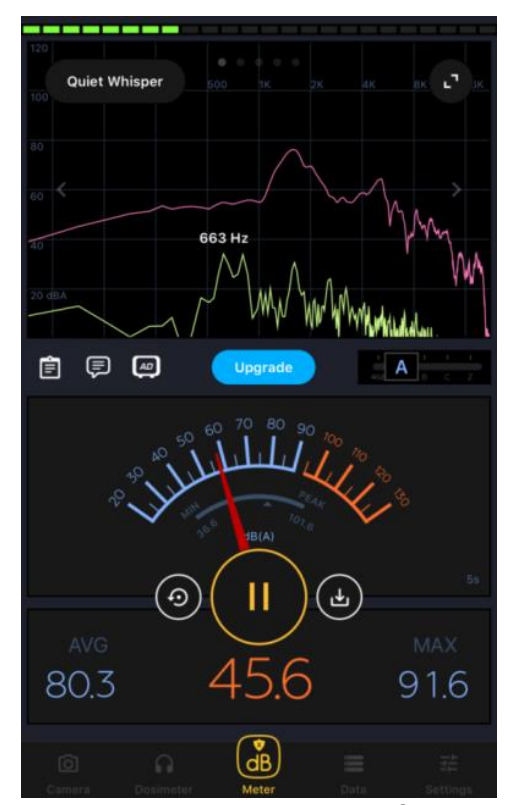

Figure 1. Screen layout in the Decibel $\mathrm{X}: \mathrm{dB}$ Sound Level Meter mobile application for noise level measurement.

The minimum and maximum as well as the mean value of noise level were recorded. All measurements were realized in two time periods during the day: morning (07.00-09.00) and afternoon (14.00-16.00) peak hours. However, the measurement was performed only at fifteen-minute intervals, given that during the pilot measurement at the intersection of Vojislava llića and Svetozara Radojčića Streets, no significant difference was observed between hourly and fifteen-minute measurement (an average noise level of $69 \mathrm{~dB}$ was recorded for one hour of measurement time, and $72 \mathrm{~dB}$ for fifteen minutes of measurement).
Table 1. Locations where noise level was measured.

\begin{tabular}{|c|c|c|}
\hline No. & Location & Zone \\
\hline 1. & $\begin{array}{c}\text { Intersection of Ustanička and } \\
\text { Vojislava llića Streets }\end{array}$ & Residential zone \\
\hline 2. & Ustanička - Krivolačka & $\begin{array}{c}\text { Zone with high traffic } \\
\text { volume }\end{array}$ \\
\hline 3. & Auto-komanda & $\begin{array}{c}\text { Zone with high traffic } \\
\text { volume }\end{array}$ \\
\hline 4. & Despot Stefan Boulevard & $\begin{array}{c}\text { Zone with high traffic } \\
\text { volume }\end{array}$ \\
\hline 5. & Uzun Mirkova Street & Central city zone \\
\hline 6. & Kalemegdan Park & Recreation zone \\
\hline 7. & Zeleni Venac & Central city zone \\
\hline 8. & Nemanjina Street & Central city zone \\
\hline 9. & Slavija Roundabout & Central city zone \\
\hline 10. & $\begin{array}{c}\text { Bulevar (Boulevard) } \\
\text { oslobodjenja }\end{array}$ & Central city zone \\
\hline 11. & King Alexander Boulevard & Residential zone \\
\hline 12. & Tašmajdan Park & Recreation zone \\
\hline 13. & Vojvode Stepe Street & Residential zone \\
\hline 14. & Trošarina & Residential zone \\
\hline 15. & Arsenija Čarnojevića Boulevard & $\begin{array}{c}\text { Zone with high traffic } \\
\text { volume }\end{array}$ \\
\hline 16. & Jurija Gagarina Street & $\begin{array}{c}\text { Zone with high traffic } \\
\text { volume }\end{array}$ \\
\hline 17. & Goce Delčeva Street & Residential zone \\
\hline 18. & Mostar Interchange & $\begin{array}{c}\text { Zone with high traffic } \\
\text { volume }\end{array}$ \\
\hline 19. & Vojvode Mišića Boulevard & $\begin{array}{l}\text { Zone with high traffic } \\
\text { volume }\end{array}$ \\
\hline
\end{tabular}

The noise level measurement was performed in the period from 01/20/2020 to 02/05/2020 (winter period with the exception of days when the frog was extremely thick, or when the rain was extremely heavy), and in the period from 07/13/2020 to 07/23/2020 (summer period). The mentioned two periods were chosen in order to analyze the noise level in relation to the reduced pedestrian flow (winter time) and the level of communal noise in real conditions (summer time).

Hereafter, all collected values will be presented, but the analysis on exposure to noise pollution will be observed only from the point of view of the obtained mean value, in related to the define ranges according to the Regulation of noise indicators, limit values, methods for assessing of noise indicators, harassments and harmful effects of noise in the environment (Official Gazette of Republic of Serbia, No. 75) (Table 2.).

Table 2. Defined noise level limits according to the Regulation of noise indicators.

\begin{tabular}{|c|c|c|c|}
\hline \multirow{2}{*}{ Zone } & \multirow{2}{*}{ Purpose of the area } & \multicolumn{2}{|c|}{ Noise level (dB) } \\
\cline { 3 - 4 } & & Day & Night \\
\hline 1. & Areas for rest and recreation & 50 & 40 \\
\hline 2. & Tourist areas & 50 & 45 \\
\hline 3. & Residential areas & 55 & 45 \\
\hline 4. & Business and residential areas & 60 & 50 \\
\hline 5. & City central & 65 & 66 \\
\hline 6. & Industrial zone & \multicolumn{2}{|c|}{$\begin{array}{c}\text { It depends on the } \\
\text { border zone }\end{array}$} \\
\hline
\end{tabular}




\section{Results}

Traffic related noise greatly contributes to the creation of so-called communal noise to which the inhabitants of an area are exposed. This communal noise has a significant impact on people's abilities and health, so it is necessary to keep it with the limits that are acceptable to the population. For the purpose of this paper, the noise level was measured in zones that are different in purpose: residential zone, zone with high traffic volume, central city zone and recreation zone. All measurements were performed in two time periods during the day: morning (07.00-09.00) and afternoon (14.00-16.00) peak hours, all measurements are performed at fifteen-minute intervals, and measurements were performed in winter and summer periods.

When it comes to the residential zone, the noise level was measured at six locations, in zone with high traffic volume at seven locations; the noise level in central city zone was measured at four locations, and at two locations which belong to the recreation zone.

\subsection{Noise level measurements during winter period}

The noise level in the residential zone was measured at six different locations. Table 3 shows that all measured mean values exceed the allowed limit of $55 \mathrm{~dB}$, which is defined according to the Regulation of noise indicators in residential zone. The highest recorded mean value of noise levels was measured near to the intersection of the Ustanička and Vojislava llića Streets (75.3dB) during the second measurement period, which was $20.3 \mathrm{~dB}$ higher than the allowed frame.

Table 3. Authoritative noise level in the residential zone in Belgrade ( $\mathrm{dB})$.

\begin{tabular}{|c|c|c|c|c|}
\hline Location & Metering & Minimum & Maximum & Mean \\
\hline \multirow{2}{*}{$\begin{array}{c}\text { Ustanička - } \\
\text { Vojislava Ilića }\end{array}$} & First & 51.2 & 97.2 & 70.6 \\
\hline & Second & 52.9 & 103.1 & 75.3 \\
\hline \multirow{2}{*}{$\begin{array}{c}\text { Bulevar } \\
\text { oslobodjenja }\end{array}$} & First & 53.6 & 87.4 & 66.9 \\
\hline & Second & 54.5 & 81.6 & 68.6 \\
\hline \multirow{2}{*}{$\begin{array}{c}\text { Vojvode Stepe } \\
\text { Street }\end{array}$} & First & 46.7 & 81.6 & 61.7 \\
\hline & Second & 49.0 & 82.0 & 62.9 \\
\hline \multirow{2}{*}{ Trošarina } & First & 50.7 & 85.9 & 65.0 \\
\hline & Second & 54.4 & 79.7 & 65.9 \\
\hline \multirow{2}{*}{$\begin{array}{c}\text { Jurija Gagarina } \\
\text { Street }\end{array}$} & First & 52.5 & 84.4 & 70.4 \\
\hline & Second & 61.7 & 93.6 & 74.0 \\
\hline \multirow{2}{*}{$\begin{array}{l}\text { Goce Delčeva } \\
\text { Street }\end{array}$} & First & 46.4 & 84.4 & 62.5 \\
\hline & Second & 51.2 & 97.3 & 69.7 \\
\hline
\end{tabular}

When it comes to zones with high volume of traffic, the noise level was measured at seven locations. The level considered as permissible for these locations is $65 \mathrm{~dB}$, according to the Regulation of noise indicators. The noise level was lower than allowed only at two locations, at the Krivolačka Street and the King Alexander Boulevard, and they were $62.7 \mathrm{~dB}$ and $64.4 \mathrm{~dB}$, respectively (both levels were recorded during the morning measurement) (Table 4).
The highest noise level in zones with high volume of traffic was recorded on the Mostar Interchange during the afternoon measurement $(83.9 \mathrm{~dB})$, which was $18.9 \mathrm{~dB}$ above the allowed frame.

The noise level in central city zone was measured at four locations in the city. At these locations, the noise level is limited to $65 \mathrm{~dB}$; at two locations (the Uzun Mirkova Street and Slavija Square) was recorded a noise level lower than allowed (Table 5), during both measurement periods (morning: $62.9 \mathrm{~dB}$ and $61.5 \mathrm{~dB}$, respectively; afternoon: $60.8 \mathrm{~dB}$ and $62.8 \mathrm{~dB}$, respectively).

Table 4. Authoritative noise level in the zone with high traffic volume in Belgrade (dB).

\begin{tabular}{|c|c|c|c|c|}
\hline Location & Metering & Minimum & Maximum & Mean \\
\hline Ustanička - & First & 48.9 & 79.1 & 62.7 \\
\cline { 2 - 5 } Krivolačka & Second & 48.5 & 94.8 & 67.5 \\
\hline \multirow{2}{*}{ Auto-komanda } & First & 59.2 & 90.3 & 67.9 \\
\cline { 2 - 5 } & Second & 56.9 & 92.1 & 68.5 \\
\hline Despot Stefan & First & 49.0 & 79.9 & 65.4 \\
\cline { 2 - 5 } Boulevard & Second & 53.2 & 91.2 & 66.3 \\
\hline King Alexander & First & 53.4 & 85.3 & 64.4 \\
\cline { 2 - 5 } Boulevard & Second & 56.2 & 81.1 & 65.5 \\
\hline A. Čarnojevića & First & 66.2 & 88.0 & 73.9 \\
\cline { 2 - 5 } Boulevard & Second & 64.0 & 102.6 & 80.3 \\
\hline Mostar & First & 69.9 & 100.1 & 82.7 \\
\cline { 2 - 5 } Interchange & Second & 71.1 & 103.0 & 83.9 \\
\hline Vojvode Mišića & First & 61.3 & 86.1 & 74.3 \\
\cline { 2 - 5 } Boulevard & Second & 60.2 & 89.4 & 75.1 \\
\hline
\end{tabular}

Table 5. Authoritative noise level in the central city zone in Belgrade (dB).

\begin{tabular}{|c|c|c|c|c|}
\hline Location & Metering & Minimum & Maximum & Mean \\
\hline \multirow{2}{*}{$\begin{array}{c}\text { Uzun Mirkova } \\
\text { Street }\end{array}$} & First & 48.6 & 79.7 & 62,9 \\
\cline { 2 - 5 } & Second & 49.6 & 75.7 & 60.8 \\
\hline \multirow{2}{*}{ Zeleni Venac } & First & 56.0 & 93.4 & 68.7 \\
\cline { 2 - 5 } & Second & 58.1 & 86.9 & 66.7 \\
\hline \multirow{2}{*}{ Nemanjina Street } & First & 57.6 & 87.5 & 67.7 \\
\cline { 2 - 5 } & Second & 58.6 & 83.1 & 67.1 \\
\hline \multirow{2}{*}{ Slavija Square } & First & 54.5 & 77.1 & 61.5 \\
\cline { 2 - 5 } & Second & 56.1 & 80.3 & 62.8 \\
\hline
\end{tabular}

The noise level in recreation zone was measured in two locations (the Kalemegdan Park and Tašmajdan Park). In recreation zone, the noise level is limited to $50 \mathrm{~dB}$, and during the measurement only once was recorded value lower than allowed, in the Kalemegdan Park (42.0dB) during the afternoon measurement (Table 6).

Table 6. Authoritative noise level in the recreation zone in Belgrade $(\mathrm{dB})$.

\begin{tabular}{|c|c|c|c|c|}
\hline Location & Metering & Minimum & Maximum & Mean \\
\hline \multirow{2}{*}{ Kalemegdan Park } & First & 39.5 & 74.2 & 55.8 \\
\cline { 2 - 5 } & Second & 35.6 & 60.2 & 42.0 \\
\hline \multirow{2}{*}{ Tašmajdan Park } & First & 45.7 & 79.3 & 54.8 \\
\cline { 2 - 5 } & Second & 46.3 & 76.4 & 55.4 \\
\hline
\end{tabular}




\subsection{Noise level measurements during summer period}

All measured mean values during the summer measurement exceed the allowed limit of $55 \mathrm{~dB}$ for residential zone (Table 7$)$. The highest recorded mean value of noise levels was measured in the Jurija Gagarina Street $(67.9 \mathrm{~dB})$ during the second measurement period, which was $12.9 \mathrm{~dB}$ higher than the allowed frame.

The noise level in zones with high volume of traffic within the permitted limits is near the building of the city municipality of Voždovac, in the Bulevar oslobodjenja (Auto-komanda), near the Faculty of Law, and the Despot Stefan Boulevard (during morning measurement) (Table 8). The highest noise level was recorded on the Mostar Interchange during the morning measurement $(78.7 \mathrm{~dB})$, which was $13.7 \mathrm{~dB}$ above the allowable limit.

Table 7. Authoritative noise level in the residential zone in Belgrade (dB).

\begin{tabular}{|c|c|c|c|c|}
\hline Location & Metering & Minimum & Maximum & Mean \\
\hline \multirow{2}{*}{$\begin{array}{c}\text { Ustanička - } \\
\text { Vojislava llića }\end{array}$} & First & 53.3 & 81.3 & 67.9 \\
\hline & Second & 53.4 & 90.5 & 66.5 \\
\hline \multirow{2}{*}{$\begin{array}{c}\text { Bulevar } \\
\text { oslobodjenja }\end{array}$} & First & 49.7 & 80.6 & 64.4 \\
\hline & Second & 50.3 & 84.3 & 64.7 \\
\hline \multirow{2}{*}{$\begin{array}{c}\text { Vojvode Stepe } \\
\text { Street }\end{array}$} & First & 40.3 & 82.2 & 60.5 \\
\hline & Second & 48.3 & 73.5 & 60.4 \\
\hline \multirow{2}{*}{ Trošarina } & First & 52.1 & 80.8 & 64.5 \\
\hline & Second & 55.9 & 83.0 & 65.7 \\
\hline \multirow{2}{*}{$\begin{array}{c}\text { Jurija Gagarina } \\
\text { Street }\end{array}$} & First & 46.7 & 80.7 & 67.1 \\
\hline & Second & 47.6 & 88.1 & 67.9 \\
\hline \multirow{2}{*}{$\begin{array}{c}\text { Goce Delčeva } \\
\text { Street }\end{array}$} & First & 49.4 & 78.8 & 64.1 \\
\hline & Second & 48.9 & 82.7 & 65.6 \\
\hline
\end{tabular}

Table 8. Authoritative noise level in the zone with high traffic volume in Belgrade $(\mathrm{dB})$.

\begin{tabular}{|c|c|c|c|c|}
\hline Location & Metering & Minimum & Maximum & Mean \\
\hline Ustanička - & First & 45.5 & 76.1 & 58.1 \\
\cline { 2 - 5 } Krivolačka & Second & 46.5 & 75.1 & 61.5 \\
\hline \multirow{2}{*}{ Auto-komanda } & First & 51.3 & 81.1 & 62.0 \\
\cline { 2 - 5 } & Second & 52.7 & 84.2 & 62.9 \\
\hline \multirow{2}{*}{$\begin{array}{c}\text { Despot Stefan } \\
\text { Boulevard }\end{array}$} & First & 49.4 & 86.7 & 63.9 \\
\cline { 2 - 5 } & Second & 54.9 & 86.4 & 65.5 \\
\hline King Alexander & First & 51.4 & 78.7 & 63.6 \\
\cline { 2 - 5 } Boulevard & Second & 54.6 & 77.7 & 64.4 \\
\hline A. Čarnojevića & First & 61.6 & 86.8 & 73.5 \\
\cline { 2 - 5 } Boulevard & Second & 62.1 & 88.3 & 74.3 \\
\hline Mostar & First & 70.3 & 92.3 & 78.7 \\
\cline { 2 - 5 } Interchange & Second & 67.9 & 85.3 & 67.9 \\
\hline Vojvode Mišića & First & 60.7 & 81.5 & 71.7 \\
\cline { 2 - 5 } Boulevard & Second & 57.2 & 86.3 & 70.7 \\
\hline
\end{tabular}

The noise level in central city zone exceeds the permitted level on the Zeleni Venac and in the Nemanjina Street (Table 9). The highest noise level was recorded on the Zeleni Venac during the afternoon measurement $(69.1 \mathrm{~dB})$, which was $4.1 \mathrm{~dB}$ above the allowable limit.
The noise level in recreation zone exceeds the allowed limit only during the afternoon measurement in the Tašmajdan Park by 2.3dB (Table 10).

Table 9. Authoritative noise level in the central city zone in Belgrade $(\mathrm{dB})$.

\begin{tabular}{|c|c|c|c|c|}
\hline Location & Metering & Minimum & Maximum & Mean \\
\hline \multirow{2}{*}{$\begin{array}{c}\text { Uzun Mirkova } \\
\text { Street }\end{array}$} & First & 44.4 & 77.0 & 58.8 \\
\cline { 2 - 5 } & Second & 48.2 & 80.5 & 60.8 \\
\hline \multirow{2}{*}{ Zeleni Venac } & First & 54.3 & 83.7 & 68.5 \\
\cline { 2 - 5 } & Second & 56.9 & 86.7 & 69.1 \\
\hline \multirow{2}{*}{ Nemanjina Street } & First & 52.9 & 85.4 & 67.9 \\
\cline { 2 - 5 } & Second & 55.0 & 81.4 & 64.9 \\
\hline \multirow{2}{*}{ Slavija Square } & First & 49.3 & 75.6 & 58.5 \\
\cline { 2 - 5 } & Second & 50.9 & 78.0 & 62.5 \\
\hline
\end{tabular}

Table 10. Authoritative noise level in the recreation zone in Belgrade (dB).

\begin{tabular}{|c|c|c|c|c|}
\hline Location & Metering & Minimum & Maximum & Mean \\
\hline \multirow{2}{*}{ Kalemegdan Park } & First & 38.6 & 63.8 & 48.9 \\
\cline { 2 - 5 } & Second & 37.9 & 62.5 & 48.9 \\
\hline \multirow{2}{*}{ Tašmajdan Park } & First & 43.1 & 64.2 & 48.8 \\
\cline { 2 - 5 } & Second & 45.9 & 74.7 & 52.3 \\
\hline
\end{tabular}

\subsection{Comparative review of noise level measurements}

The noise level measurements were performed during two different seasons. The reason for this is to show the noise level in the winter period when there is a significantly lower number of pedestrians as road users, as well as the noise level in the summer period when several different sources contribute the level of communal noise. However, it is important to note that the two different seasons represent significant temperature differences that also affect the movement of sound. Namely, air molecules are grouped during cold periods, which allows the sound wave to travel further (the reason for this lies in the slower movement of the sound wave); while, on the other hand, air molecules are scattered during warm weather, where sound waves and molecules collide, making the sound weaker (the reason for this lies in the faster movement of the sound wave) (medium.com - visited $11 / 14 / 2020)$. Having previously in mind, below is a comparative view of noise levels during the winter and summer measurements.

In the residential zone, it was noted that the noise level was higher during the summer period only in the Goce Delčeva Street, compared to the winter period (Table 11). At all other locations it was noted that the noise level was higher during the winter measurement. The largest difference was recorded at the intersection of the Ustanička and Vojislava Ilića Streets $(\Delta=8.8 \mathrm{~dB})$ during the afternoon measurement, while the smallest difference was observed at the Trošarina during both measurements $(\Delta=0.5 \mathrm{~dB}$ and $\Delta=0.2 \mathrm{~dB}$, respectively). 
Table 11. Comparative presentation of noise levels in the residential zone in Belgrade $(\mathrm{dB})$.

\begin{tabular}{|c|c|c|c|c|}
\hline \multirow{2}{*}{ Location } & Metering & $\begin{array}{c}\text { Winter } \\
\text { metering }\end{array}$ & $\begin{array}{c}\text { Summer } \\
\text { metering }\end{array}$ & $\boldsymbol{\Delta}$ \\
\hline $\begin{array}{c}\text { Ustanička - } \\
\text { Vojislava llića }\end{array}$ & First & 70.6 & 67.9 & 2.7 \\
\cline { 2 - 5 } & Second & 75.3 & 66.5 & 8.8 \\
\hline $\begin{array}{c}\text { Bulevar } \\
\text { oslobodjenja }\end{array}$ & First & 66.9 & 64.4 & 2.5 \\
\cline { 2 - 5 } Vojvode Stepe & Second & 68.6 & 64.7 & 3.9 \\
\hline Street & First & 61.7 & 60.5 & 1.2 \\
\cline { 2 - 5 } & Second & 62.9 & 60.4 & 2.5 \\
\hline \multirow{2}{*}{\begin{tabular}{c} 
Trošarina \\
\cline { 2 - 5 }
\end{tabular}} & First & 65.0 & 64.5 & 0.5 \\
\hline Jurija Gagarina & Second & 65.9 & 65.7 & 0.2 \\
\cline { 2 - 5 } Street & First & 70.4 & 67.1 & 3.3 \\
\hline Goce Delčeva & First & 74.0 & 67.9 & 6.1 \\
\cline { 2 - 5 } Street & Second & 69.5 & 64.1 & -1.6 \\
\hline
\end{tabular}

A significantly higher noise level was recorded during the winter measurement period at all locations in the zones with high volume of traffic (Table 12). The largest difference was observed near the building of the city municipality of Voždovac and in the Arsenija Čarnojevića Boulevard during the afternoon measurement $(\Delta=6.0 \mathrm{~dB})$, while the smallest difference was also observed in the Arsenija Čarnojevića Boulevard during the morning measurement $(\Delta=0.4 \mathrm{~dB})$.

Table 12. Comparative presentation of noise levels in the zone with high traffic volume in Belgrade $(\mathrm{dB})$.

\begin{tabular}{|c|c|c|c|c|}
\hline \multirow{2}{*}{ Location } & Metering & $\begin{array}{c}\text { Winter } \\
\text { metering }\end{array}$ & $\begin{array}{c}\text { Summer } \\
\text { metering }\end{array}$ & $\boldsymbol{\Delta}$ \\
\hline \multirow{2}{*}{$\begin{array}{c}\text { Ustanička - } \\
\text { Krivolačka }\end{array}$} & First & 62.7 & 58.1 & 4.6 \\
\cline { 2 - 5 } & Second & 67.5 & 61.5 & 6.0 \\
\hline \multirow{2}{*}{ Auto-komanda } & First & 67.9 & 62.0 & 5.9 \\
\cline { 2 - 5 } & Second & 68.5 & 62.9 & 5.6 \\
\hline Despot Stefan & First & 65.4 & 63.9 & 1.5 \\
\cline { 2 - 5 } Boulevard & Second & 66.3 & 65.5 & 0.8 \\
\hline King Alexander & First & 64.4 & 63.6 & 0.8 \\
\cline { 2 - 5 } Boulevard & Second & 65.5 & 64.4 & 1.1 \\
\hline \multirow{2}{*}{$\begin{array}{c}\text { A. Čarnojevića } \\
\text { Boulevard }\end{array}$} & First & 73.9 & 73.5 & 0.4 \\
\cline { 2 - 5 } & Second & 80.3 & 74.3 & 6.0 \\
\hline Mostar & First & 82.7 & 78.7 & 4.0 \\
\cline { 2 - 5 } Interchange & Second & 83.9 & 67.9 & 16.0 \\
\hline Vojvode Mišića & First & 74.3 & 71.7 & 2.6 \\
\cline { 2 - 5 } Boulevard & Second & 75.1 & 70.7 & 4.4 \\
\hline
\end{tabular}

The largest difference in the noise level in central city zone was observed in the Uzun Mirkova Street during the morning measurement $(\Delta=4.1 \mathrm{~dB})$, while no difference in the noise level was observed during the afternoon measurement $(\Delta=0.0 \mathrm{~dB})$ (Table 13). The smallest difference was observed on the Zeleni Venac during the morning measurement $(\Delta=0.2 \mathrm{~dB})$ and on the Slavija Square during the afternoon measurement $(\Delta=0.3 \mathrm{~dB})$. In addition, during the summer measurements were observed the higher noise levels on the Zeleni Venac during the afternoon measurement and in the Nemanjina Street during the morning measurement.
Table 13. Comparative presentation of noise levels in the central city zone in Belgrade $(\mathrm{dB})$.

\begin{tabular}{|c|c|c|c|c|}
\hline Location & Metering & $\begin{array}{c}\text { Winter } \\
\text { metering }\end{array}$ & $\begin{array}{c}\text { Summer } \\
\text { metering }\end{array}$ & $\boldsymbol{\Delta}$ \\
\hline \multirow{2}{*}{$\begin{array}{c}\text { Uzun Mirkova } \\
\text { Street }\end{array}$} & First & 62.9 & 58.8 & 4.1 \\
\cline { 2 - 5 } & Second & 60.8 & 60.8 & 0.0 \\
\hline \multirow{2}{*}{ Zeleni Venac } & First & 68.7 & 68.5 & 0.2 \\
\cline { 2 - 5 } & Second & 66.7 & 69.1 & -2.4 \\
\hline \multirow{2}{*}{ Nemanjina Street } & First & 67.7 & 67.9 & -0.2 \\
\cline { 2 - 5 } & Second & 67.1 & 64.9 & 2.2 \\
\hline \multirow{2}{*}{ Slavija Square } & First & 61.5 & 58.5 & 3.0 \\
\cline { 2 - 5 } & Second & 62.8 & 62.5 & 0.3 \\
\hline
\end{tabular}

The largest difference between the winter and summer period was observed in the Kalemegdan Park during the morning measurement $(\Delta=6.9 \mathrm{~dB})$, but also the increased in noise level during the summer period at the time of the afternoon measurement (Table 14). The reason for that may be the increased number of citizens in this part of the city, i.e. in recreation zone itself.

Table 14. Comparative presentation of noise levels in the recreation zone in Belgrade $(\mathrm{dB})$.

\begin{tabular}{|c|c|c|c|c|}
\hline \multirow{2}{*}{ Location } & Metering & $\begin{array}{c}\text { Winter } \\
\text { metering }\end{array}$ & $\begin{array}{c}\text { Summer } \\
\text { metering }\end{array}$ & $\boldsymbol{\Delta}$ \\
\hline \multirow{2}{*}{ Kalemegdan Park } & First & 55.8 & 48.9 & 6.9 \\
\cline { 2 - 5 } & Second & 42.0 & 48.9 & -6.9 \\
\hline \multirow{2}{*}{ Tašmajdan Park } & First & 54.8 & 48.8 & 6.0 \\
\cline { 2 - 5 } & Second & 55.4 & 52.3 & 3.1 \\
\hline
\end{tabular}

\section{Discussion and conclusion}

Noise as a consequence of traffic is, in addition to air pollution, the second source of environmental pollution. Every third person has experienced mild anxiety, and every fifth sleep problems due to traffic related noise (Mihajlov et al., 2015). Noise can have short- and long-term consequences for humans, such as various forms of stress, sleep disorders, cognitive impairment, high blood pressure, hearing loss, development of cardiovascular and respiratory diseases and the like.

Even if traffic contributes the most to the development of noise in the environment $(712,648$ motor vehicles were registered in Belgrade during 2019. (Statistical Office of the Republic of Serbia, 2020)), it is necessary to talk about communal noise, which is actually a combination of all sources of noise in the environment (traffic, construction, society...). The reason for that lies in the goal of creating the sustainable cities, i.e. cities sustainable for human life which are economically, ecologically and health-wise tailored to citizens. Urban road safety also contributes to this, according to which the goal is no longer only the prevention of traffic accidents and the reduction of their consequences, but also the overall reduction of all harmful consequences of traffic (Zivkovic and Todorovic, 2020). 
In this regard, this paper presents the results of measuring noise levels at 19 locations in the city of Belgrade. All locations are divided in the four zones: residential zone, zone with high volume of traffic, central city zone and recreation zone. Since it is about different purposes of zones and also about different allowed limits of noise levels this division of zones was used. The measurement was performed during the winter and summer period, and during the morning and afternoon peak hours. The winter period was chosen due to the reduction volume of pedestrian traffic, which shows the approximately exact level of traffic noise; while, on the other hand, the summer period was chosen to show the approximate level of communal noise. The measurement was performed at fifteenminute intervals.

The applied and presented method of the noise level measurement showed that an increased noise level was achieved in relation to the allowed limits at most locations during the winter measurement period. Exceeding the noise level ranges from $0.5 \mathrm{~dB}$ in a zone with high volume of traffic to $20.3 \mathrm{~dB}$ for a residential zone. Measurement locations such as Uzun Mirkova Street and Slavija Square have a mean value of noise level lower than the permitted limit for central city zone $(65 \mathrm{~dB})$ during both measurement periods.

During the summer measurement period, a significantly higher number of locations were recorded that had a lower mean value of noise levels that the permitted limit. However, the noise level in residential zone exceeds the permitted limits at all measurement locations, as is the case in the winter measurement period. Measurement locations such as UstaničkaKrivolačka, Auti-komanda, King Alexander Boulevard, Uzun Mirkova Street, Slavija Square and Kalemegdan Park have a mean value of noise levels lower that the allowed limit during both measurement periods. The minimum and maximum mean value of exceeding the noise level was recorded in zone with high volume of traffic, and it is $0.5 \mathrm{~dB}$ and $13.7 \mathrm{~dB}$, respectively. However, it is important to note that there is a natural difference in the movement of sound during the winter and summer periods. This is also shown by the comparative analysis of the noise level, where a higher noise level was recorded during the winter measurement period. The largest difference between the two measurement periods was observed on the Mostar Interchange $(\Delta=16 \mathrm{~dB})$, and the smallest in the Uzun Mirkova Street $(\Delta=0 \mathrm{~dB})$ during the afternoon measurement.

One of the measures of urban road safety supported by a large number of authors is the change of the purpose of the area (Zivkovic and Todorovic, 2020; Pisoni et al., 2019; Schreuer et al., 2019; Szarata et al., 2017; Feng Wei and Lovegrove, 2012). For example, a pilot measurement (executed by the author for the purpose of this paper) in the event of the closure of the King Milan Street for motor traffic (measuring location - Slavija Square - 09/19/2020), can achieve a significant reduction in communal noise level (Table 15) during both measurement periods (10dB and $7 \mathrm{~dB}$ for winter period, and $7 \mathrm{~dB}$ for summer period). Any decrease of the mean value of noise level by $1 \mathrm{~dB}$ can lead to a reduction in annual mortality from cardiovascular and respiratory diseases by 193 and 71, respectively (Recio et al., 2017).

Table 15. Pilot measuring of noise level in the conditions of the change purpose of the surface - Slavija Square $(\mathrm{dB})$.

\begin{tabular}{|c|c|c|c|c|}
\hline Location & Metering & $\begin{array}{c}\text { Winter } \\
\text { metering }\end{array}$ & $\begin{array}{c}\text { Summer } \\
\text { metering }\end{array}$ & $\begin{array}{c}\text { Pilot } \\
\text { metering }\end{array}$ \\
\hline Slavija & First & 61.5 & 58.5 & 50.8 \\
\cline { 2 - 5 } Square & Second & 62.8 & 62.5 & 55.4 \\
\hline
\end{tabular}

Fallowing above, the implementation of Sustainable Urban Mobility Plan (2020), as a policy measure, can contribute to the development of urban mobility, but also to a significant reduction in noise level in the urban environment. Namely, the conversion of certain parts of the city into pedestrian areas, with a reduction number of motor vehicles (or a complete prohibition of access to motor vehicles) and with more green elements can contribute to reduction of communal noise level, and above all the traffic related noise.

Since this paper used a fifteen-minute interval for measuring noise level, the proposal for further work is directed at using the mean value of day and night noise levels, obtained through checkpoints at certain locations in the city of Belgrade. As a large number of authors believe that noise should be observed in conjunction with air pollution by exhaust gases (So et al., 2020; Tezel et al., 2019; Recio et al., 2017), the proposal is to perform additional comparative measurement of noise level and $\mathrm{SO}_{2}, \mathrm{NO}_{x}, \mathrm{CO}, \mathrm{PM}_{10}$ and $\mathrm{PM}_{2,5}$.

\section{Ниво амбијенталних звукова као индикатор урбане безбедности саобраћаја}

Филип Живковић, дипл. инж. саоб.

Универзитет у Београду, Саобраћајни факултет

Резиме: Одвијање саобраћаја у урбаним срединама довело је до загађења животне средине буком. Међутим, саобраћај није једини извор буке, тако да се о буци у животној средини говори као о комуналној буцу која представља комбинацију више извора. Сви ти извори могу довести до појаве разних последица на здравље човека, као што су: стресови, зујање у ушима, кардиоваскуларна и респираторна обољења и смрт у екстремним случајевима. С тим у вези, извршено је мерење нивоа амбијенталних звукова на 19 локација у граду Београду, током зимског и летњег периода. Циљ овог рада је приказати ниво амбијенталних звукова као индикатор урбане безбедности саобраћаја, на основу чега би било могуће употпунити циљеве стварања градова погодних за живот грађана.

Кључне речи: Бука одвијања саобраћаја, Урбана безбедност саобраћаја, Јавно здравље, Индикатори безбедности саобраћаја 


\section{References}

[1] Andersson E.M., Ögren M., Molnár P., Segersson D., Rosengren A., Stockfelt L. (2020), Road traffic noise, air pollution and cardiovascular events in a Swedish cohort, Environmental Research 185, 109446

[2] Antic B., Vujanic M., Pesic D., Pesic D. (2012), Traffic noise pollution in Belgrade by using zonal evaluation method, Technics Technologies Education Management 7, 484-492

[3] Directive 2002/49/EC of the European Parliament and of the Council of 25 June 2020

[4] Djeric B., Trifunovic A., Cicevic S., Josic A., Stokic I. (2018), Measuring the noise emissions of motor vehicles in the territory of the city Kragujevac, Journal of Road and Traffic Engineering LXIV, 1/2018, 61-66

[4] Douglas M.J., Watkins S.J., Gorman D.R., Higgins M. (2011), Are cars the new tobacco?, Journal of Public Health 33, 160-169

[5] European Environmental Agency (2017), Road traffic remains biggest source of noise pollution in Europe

[6] Feng Wei V., Lovegrove G. (2012), Sustainable road safety: A new (?) neighborhood road pattern that saves VRU lives, Accident Analysis and Prevention 44, 140-148

[7] Halonen J.I., Hansell A.L., Gulliver J., Morley D., Blangiardo M., Fecht D., Toledano M.B., Beevers S.D., Anderson H.R., Kelly F.J., Tonne C. (2015), Road traffic noise is associated with increased cardiovascular morbidity and mortality and all-cause mortality in London, European Heart Journal 36, 2653-2661

[8] Héritier H., Vienneau D., Foraster M., Eze I.C., Schaffner E., de Hoogh K., Thiesse L., Rudzik F., Habermacher M., Köpfil M., Pieren R., Brink M., Cajochen C., Wunderli J.M., Rrobst-Hensch N., Röösli M. (2019), A systematic analysis of mutual effects of transportation noise and air pollution exposure on myocardial infarction mortality: a nationwide cohort study in Switzerland, European Heart Journal 40, 598-603

[9] Klompmaker J.O., Hoek G., Bloemsma L.D., Wijga A.H., van den Brink C., Brunekreef B., Lebret E., Gehring U., Janssen N.A.H. (2019), Associations of combined exposures to surrounding green, air pollution and traffic noise on mental health, Environmental Research 129, 525-537

[10] Klompmaker J.O., Hoek G., Bloemsma L.D., Marra M., Wijga A.H., van den Brink C., Brunekreef B., Lebret E., Gehring U., Janssen N.A.H. (2020), Surrounding green, air pollution, traffic noise exposure and non-accidental and cause-specific mortality, Environmental International 134, 105341

[11] Manojlović P., Stošić L. (2016.), Urban management and environmental management in the city in the conditions of the permanent intensification road, $4^{\text {th }}$ International Conference Contemporary achievements in civil engineering, 22. April 2016, Subotica, Serbia

[12] medium.com - visited 11/14/2020

[13] Mihajlov D., Praščević M., Gajicki A. (2015.), Assesment of harmful health impact of environmental noise, Working and Living Environmental Protection 12, 9-16

[14] Münzel T., Sørensen M., Gori T., Schmidt F.P., Rao X., Brook J., Chen L.C., Brook R.D., Rajagopalan S. (2017), Environüental stressors and cardio-metabolic disease: part I - epidemiologic evidence supporting a role from noise and air pollution and effects of mitigation strategies, European Heart Journal 38, 550 556

[15] Official Gazette of Republic of Serbia, Regulation of noise indicators, limit values, methods for assessing of noise indicators, harassments and harmful effects of noise in the environment (No. 75)
[16] Oudin A. (2020), Short review: Air pollution, noise and lack of green as risk factors for Alzheimer's disease - epidemiologic and experimental evidence, Neurochemistry International 134, 104646

[17] Pecić L., Pravdić P. (2019), Road traffic as a source of noise pollution (case stady: Trstenik Municipality), Journal of Economics, Management and Informatics, 69-83

[18] PIARC (2020), Traffic noise - Best practice guide

[19] Pisoni E., Christidis P., Thunis P., Trombetti M. (2019), Evaluating the impact of "Sustainable urban Mobility Plans" on urban background and qualitu, Journal of Environmental Management 231, 249-255

[20] Recio A., Linares C., Banegas J.R., Díaz J. (2016), Road traffic noise effects on cardiovascular, respiratory, and metabolic health: An integrative model of biological mechanisms, Environmental Research 146, 359-370

[21] Recio A., Linares C., Banegas J.R., Díaz J. (2017), Impact of road traffic noise on cause-specific mortality in Madrid (Spain), Science of the Total Environmental 590-591, 171-173

[22] Report on the implementation of the $G 2 G$ project for Serbia G2G09/SB/5/5 (2011), Reduction of traffic noise in Serbia

[23] Schreuer N., Plaut P., Lihi G., Dalia S. (2019), The relations between walkable neighborhoods and active participation in daily activity of people with disabilities, Journal of Transport \& Health 15,100630

[24] Secretariat for Transport, CEP, CeS.TRA (2020), Sustainable urban mobility plan - Belgrade

[25] So R., Jørgensen J.T., Lim Y.H., Mehta A.J., Amini H., Mortensen L.H., Westendrop R., Ketzel M., Hertel O., Brandt J., Christensen J.N., Geels C., Frohn L.M., Sisgaard T., Bräuner E.V., Jensen S.S., Backalarz C., Simonsen M.K., Loft S., Cole-Hunter T., Jovanovic Anderson Z. (2020), Long-term exposure to low levels of air pollution and mortality adjusting for road traffic noise: A Danish Nurse Cohort study, Environmental International 143, 105983

[26] Statistical Office of the Republic of Serbia, Registered road motor vehicles and trailers and road traffic accidents, 2019, NUMBER 050, 09/03/2020

[27] Sygna K., Marit Aasvang G., Aamodt G., Oftedal B., Hjertager Krog N. (2014), Road traffic noise, sleep and mental health, Environmental Research 131, 17-24

[28] Szarta A., Nosal K., Duda-Wiertel U., Franek L. (2017), The impact of the car restrictions implemented in the city center on the public space quality, Transport Research Procedia 27, 752-759

[29] Tezel M.N., Sari D., Ozkurt N., Keskin S. (2019), Combined NOx and noise pollution from road traffic in Trabzon, Turkey, Science of the Total Environment 696, 134044

[30] World Health Organization (2011), Burden of disease from environmental noise.

[31] World Health Organization (2018), Global status report on road safety 2018.

[32] Yang W., He J., He C., Cai M. (2020), Evaluation of urban traffic noise pollution based on noise maps, Transport Research Part D 87, 102516

[33] Yu Y., Paul K., Arah O., Mayeda E., Wu J., Lee E., Ritz B. (2020), Air pollution, noise exposure, and metabolic syndrome - A cohort study in elderly Mexican-Americans in Sacramento area, Environmental International 134, 105269

[34] Zivkovic F., Todorovic O.P. (2020), Road safety in the Function of sustainable cities - Literary review, $9^{\text {th }}$ International Conference "Road Safety in Local Communities", Republic of Srpska, Banja Luka, October 29-30, 2020 